\title{
Notes on the vocalizations of Elegant Mourner (Laniisoma elegans)
}

Peter Boesman

In the following we briefly analyze and compare voice of the different races of Elegant Mourner (Laniisoma elegans). We also try to quantify the extent of any vocal differences using the criteria proposed by Tobias et al. (2010), as a support for taxonomic review. We have made use of sound recordings available on-line from Xeno Canto (XC) and Macaulay Library (ML).

Song of both groups (Andean and Atlantic) is similar, a series of high-pitched underslurred whistles (Fig. 1).

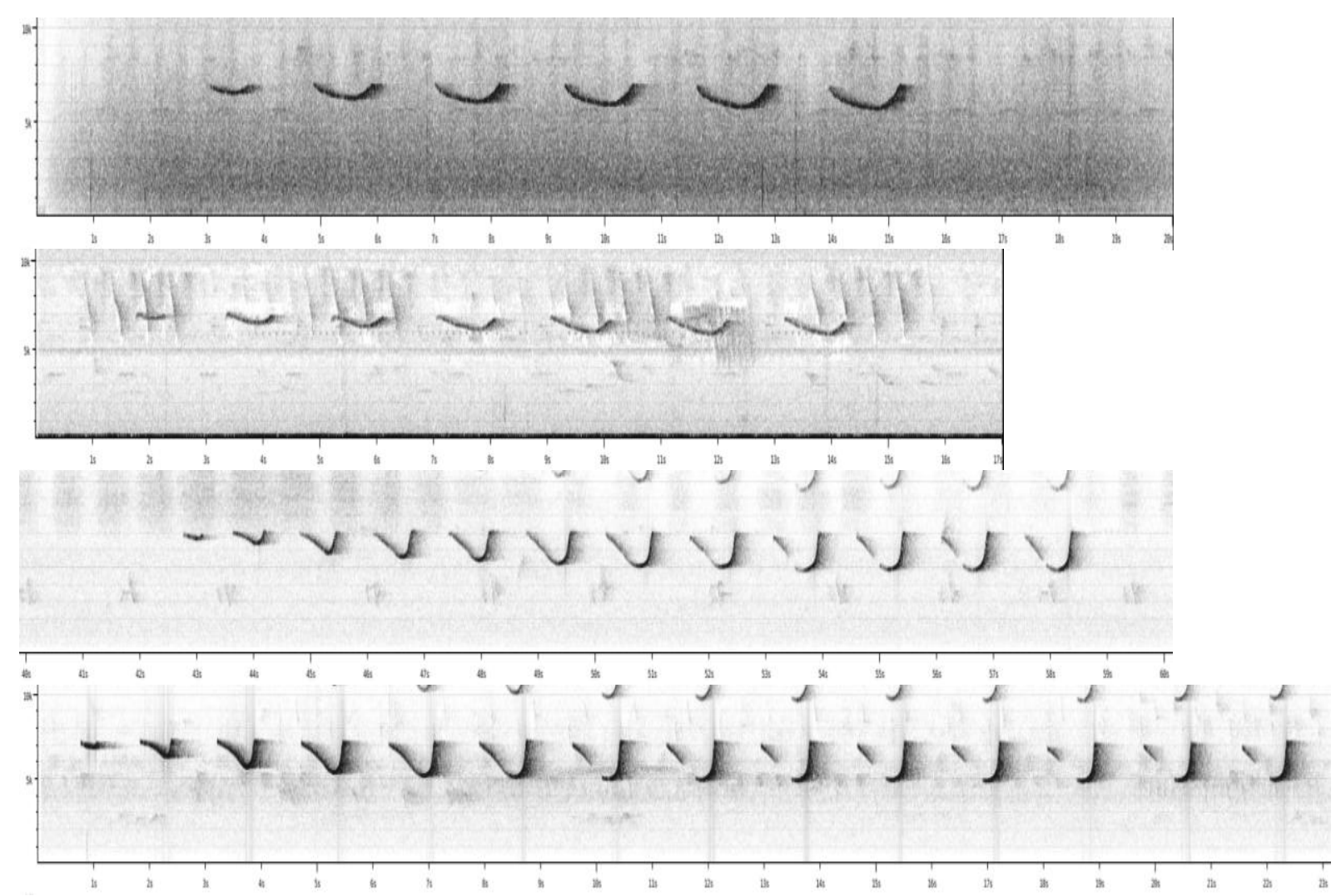

Figure 1: typical examples of song, top two buckleyi, bottom two elegans

There are however some obvious differences, for which we have measured a number of basic sound parameters: 

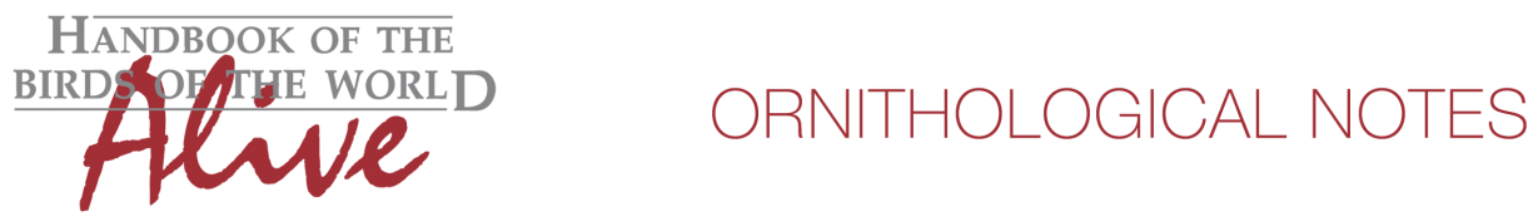

Andean group (only recordings of buckleyi !!)( $\mathrm{n}=9)$

$\begin{array}{ll}\text { \# notes } & 5-8 \\ \text { total length } & 10-16 \mathrm{~s} \\ \text { max. note length } & 1.07-1.3 \mathrm{~s} \\ \text { lowest freq. } & 4700-5600 \mathrm{~Hz} \\ \text { highest freq. } & 6400-7200 \mathrm{~Hz} \\ \text { max freq. range 1 note } & 1000-1400 \mathrm{~Hz} \\ & \\ \text { Atlantic group (elegans) }(\mathrm{n}=8) \\ \text { \# notes } & 8-15 \\ \text { total length } & 11-22 \mathrm{~s} \\ \text { max. note length } & 0.65-0.9 \mathrm{~s} \\ \text { lowest freq. } & 3400-4500 \mathrm{~Hz} \\ \text { highest freq. } & 5200-7000 \mathrm{~Hz} \\ \text { max freq. range } 1 \text { note } & 1300-2400 \mathrm{~Hz}\end{array}$

From the above measurements, it is clear that song of Andean group has fewer notes (score 1-2) longer in duration (score 2-3), which don't go as low in frequency (score 1-2) and thus frequency range of single notes is smaller (score 1-2).

When applying Tobias criteria, the total score for vocal differences is about 4.

This note was finalized on 10th June 2015 , using sound recordings available on-line at that moment. We would like to thank in particular the sound recordists who placed their recordings for this species on XC and ML: Nick Athanas, Rodrigo de la Rosa, Ricardo Gagliardi, Niels Krabbe, Bernardo Lacombe, Jeremy Minns, John V Moore, Jonas Nilsson, Ted Parker, Eduardo Patrial, Leonardo Pimentel, Glenn Seeholzer and Charlie Vogt.

\section{References}

Tobias, J.A., Seddon, N., Spottiswoode, C.N., Pilgrim, J.D., Fishpool, L.D.C. \& Collar, N.J. (2010). Quantitative criteria for species delimitation. Ibis 152(4): 724-746.

\section{Recommended citation}

Boesman, P. (2016). Notes on the vocalizations of Elegant Mourner (Laniisoma elegans). HBW Alive Ornithological Note 114. In: Handbook of the Birds of the World Alive. Lynx Edicions, Barcelona. (retrieved from http://www.hbw.com/node/932019 on 3 August 2016). 